\title{
Evaluation of Biogas Production from the Co-Digestion of Banana Fruit Peels and Poultry Manure
}

\author{
Tesfaye Menta \\ Department of Biology, Stream of Biotechnology, College of Natural and Coputational Science, Haramaya \\ University, Ethiopia.
}

\begin{abstract}
Substances have different degrees of degradability. Low degradability of substrates is one of the factors that hinder the production of biogas from organic substances. To overcome this low degradability of substrates, mixing is important for most of the substrates. With the aim of maximizing biogas yields from co-digestion of banana fruit peel and poultry manure, a series of experiments were carried out under mesophilic conditions at $38^{\circ} \mathrm{C}$ using batch digester operating for 25 days hydraulic retention time (HRT). Anaerobic degradability test with mix of 5 different proportions were carried out to obtain suitable mix ratio for maximum biogas production from co-digestion of BP and PM. The objective of this study was to determine the biogas yield from solo and co-digestion of BP and PM. Production of biogas through anaerobic digestion of organic waste materials provides an alternative environmentally, eco- friendly renewable energy. In all treatments; TS, VS, organic carbon and pH were measured before and after digestion. The daily biogas production was subsequently measured by water displacement method for 25 days. Gas production was noticed in all of the substrate types from the first day up to the $25^{\text {th }}$ day of digestion. Assessment of cumulative biogas production revealed that substrates in mix ratios showed high biogas yield. The highest yield was recorded insubstrate mix ratio of 50\% $\mathrm{BP}+50 \% \mathrm{PM}$, suggesting that this mix ratio of the two substrates is an optimal mix to yield better amount of biogas. Overall results indicated that production of biogas yield from substrates and reduction in VS and TS can be significantly enhanced when BP and PM are co-digested. Keywords: Banana peel, Biogas, Co-digestion, Poultry manure, Total solids, Volatile solid
\end{abstract}

DOI: $10.7176 /$ JETP/10-2-03

Publication date: April $30^{\text {th }} 2020$

\section{INTRODUCTION}

Currently, renewable energy resources are being used as the major contributors (with approximately $24 \%$ contribution) of the global energy demand (Converti et al., 2009). The most common forms of renewable energy considered are the solar, geothermal, water, wind and finally the biomass related energy such as biogas. Some of the most important benefits of using renewable energy are based on the organic composition, lack of fossil derived $\mathrm{CO}_{2}$ emission, the use of mainly locally available inexpensive resources and the fact that they are the best solutions covering directly the need of the local community (Popescu, 2010)

Biogas is an alternative and renewable energy source produced through anaerobic digestion process, which is a natural biological process in which an interlaced community of bacteria cooperate to obtain fermentation through assimilation, transformation and decomposition of organic matter into biogas. This is a complex multistep process in terms of microbiology, where the organic material is degraded to obtain methane gas under the absence of oxygen.

Biogas is produced by the decomposition of organic matter in the absence of oxygen. For typical biogas systems, this organic matter can include manure or plant substrates like crops or food waste, for example, fruit peels. These inputs are fed into anaerobic digester where microbes in the presence of heat and absence of oxygen break down organic matter and

Ethiopia is one of the top ranking countries in Africa and among the first ten in the world in terms of livestock resource (FAO, 2009). Majority of the rural population in Ethiopia is involved in some ways in animal husbandry. So, the country has the greatest potential to the development of biogas technology (Zenebe et al., 2010). Biogas technology is a modern and eco-friendly technology based on the decomposition of organic materials in anaerobic environment at suitable and stable temperature by anaerobic bacteria. Anaerobic digestion consists of several interdependent, complex sequential and parallel biological reactions in the absence of oxygen during which the products from one group of microorganisms serve as the substrates for the next, resulting in transformation of organic matter (biomass) mainly into a mixture of methane and carbon dioxide commonly referred to as biogas (Werner et al., 1989).

Apart from the benefits of biogas for cooking and lighting, the effluent that comes as slurry is rich with various plant nutrients such as nitrogen, phosphorous, and potash, which are essential for plant growth. Well fermented bio-slurry improves the physical, chemical, and biological properties of the soil resulting in enhancing qualitative as well as quantitative yield of food crops. The slurry is relatively free of parasites and pathogens, it is highly recommended for use in farming. The economic value of the slurry is high because it saves the money for importing inorganic fertilizers and it improves the yield more than inorganic fertilizer by adding both micro and 
macro nutrients to the soil (Fisseha, 1991 and Fentaw et al., 2010). Furthermore, biogas is also improving the environment indoors and outdoors. The indoor environment is enhanced by reduction in the incidents of illness from burning of firewood and dung, outdoors by reduction in carbon dioxide and methane emissions (Siltan, 1985). Biogas is a flammable gas made of a mixture of gases produced by methanogenic bacteria while acting upon biodegradable materials in an anaerobic condition. Biogas is mainly composed of 50 to 70 percent methane $\left(\mathrm{CH}_{4}\right)$, 30 to 40 percent carbon dioxide $\left(\mathrm{CO}_{2}\right)$ and traces such as $\mathrm{H}_{2} \mathrm{~S}, \mathrm{~N}_{2}, \mathrm{NH}_{3}$ and $\mathrm{CO}$ (Claude, 2009).

\section{MATERIALS AND METHODS}

\subsection{Description of the Study Area}

The study was conducted at Haramaya University, which is located $510 \mathrm{~km}$ East of Addis Ababa, Ethiopia. The geographical location is $9^{0} 24^{\prime} \mathrm{N}$ and $42^{\circ} 03^{\prime} \mathrm{E}$. The average altitude of the area, which is about $1980 \mathrm{~m}$ above sea level, mostly puts the place into the category of Ethiopian highlands. The experiment was conducted in biotechnology lab by constructing a model lab-scale anaerobic digester.

\subsection{Sample Collection and Preparation}

Banana fruit peels and poultry manure were used as feed stocks for the generation of biogas. Fresh poultry manure $(3.5 \mathrm{Kg})$ was collected from Haramaya University poultry farm while banana fruit peels $(4 \mathrm{Kg})$ were collected from nearby towns (Harar city and Haramaya town). The rumen fluid used as inoculum to start anaerobic digestion was obtained from the slaughter house of Haramaya University. The collected banana fruit peels were frist cut with scissors and knife into small pieces and allowed to dry under shade condition for three days and ground into fine sizes (Fulford, 1988).

\subsection{Determination of the Physico-chemical Properties of Feed Stocks}

\subsubsection{Total Solids (TS)}

For the determination of TS, a clean evaporating dish was first dried in an oven adjusted at $105^{\circ} \mathrm{C}$ for 1 hour, cooled in desiccators and weighed immediately before use. Then, $10 \mathrm{~g}$ of freshly collected samples of each of poultry manure and banana fruit peels were weighed using a digital balance, and placed onto a pre-dried and weighed evaporating dish. Then, the dish was put inside an electric hot oven maintained at $105^{\circ} \mathrm{C}$. The crucible (the dish) was allowed to stay in the oven for 24 hours, and then taken out, cooled in desiccators and weighed (APHA $2540 \mathrm{~B}, 1999$ ). Then, the percentage of the TS was calculated as follows:

Where,

$$
\% \mathrm{TS}=\frac{\mathrm{mDS}}{\mathrm{mFS}} \times 100
$$

$$
\begin{aligned}
& \% \mathrm{TS}=\text { percentage of total solids } \\
& \mathrm{mDS}=\text { mass of dry sample (final weight) in gram } \\
& \mathrm{mFS}=\text { mass of fresh sample in gram }
\end{aligned}
$$

\subsubsection{Volatile and Fixed Solids}

Once the TS was determined, the oven dried substrate was ignited at $550^{\circ} \mathrm{C}$ in a muffle furnace for 3 hours to determine the volatile and fixed solid content of the substrate. The following formula was employed to calculate the percentage of volatile solids content of TS (APHA $2540 \mathrm{E}, 1999)$ ).

Where,

$$
\% \mathrm{VS}=\frac{\mathrm{mDS}-\mathrm{m}(\mathrm{ash})}{\mathrm{mDS}} \mathrm{X} 100
$$

$\% \mathrm{VS}=$ percentage of volatile solids

$\mathrm{m} \mathrm{DS}=$ mass of dry solids in gram

$\mathrm{m}(\mathrm{ash})=$ remaining mass after ignition $=$ fixed solid in gram .

i.e. $\mathrm{TS}=\mathrm{VS}+\mathrm{FS}$

The percentage VS removal was calculated using the equation below.

Where,

$$
\text { VS removal }(\%)=\frac{V S i-V S f}{V S i} \times 100
$$

$\mathrm{VSi}=$ initial volatile solids $(\%)$ before AD

$\mathrm{VSf}=$ final volatile solids $(\%)$ after AD

\subsubsection{Carbon content}

The carbon content of the feed stock was measured by considering the volatile solids content that was expressed as a percentage and the total carbon content was obtained from volatile solids data using an empirical equation as reported by Haug (1993) and Barrington et al., (2002)

Where,

$$
\% \text { Carbon }=\frac{\% \mathrm{VS}}{1.8}
$$


$\mathrm{VS}=$ Volatile solids

\subsection{Feedstock Composition}

Each digester contained fixed amount of poultry manure (PM) and banana fruit peel (BP). The digester was filled with fresh poultry manure and banana fruit peels combined in different proportions to determine the optimal mix ratio reguired for maximum biogas production. The combinations were done in five treatment proportions, i.e., Treatment one $(\mathrm{T} 1)=100 \% \mathrm{BP}$, Treatment two $(\mathrm{T} 2)=75 \% \mathrm{BP}+25 \% \mathrm{PM}$, Treatment three $(\mathrm{T} 3)=50 \% \mathrm{BP}+50 \%$ $\mathrm{PM}$, Treatment four (T4) $=25 \% \mathrm{BP}+75 \% \mathrm{PM}$ and Treatment five $(\mathrm{T} 5)=100 \% \mathrm{PM}$. To each of the treatment, appropriate amount of distilled water and inoculum were added to achieve the recommended $8 \%(\mathrm{w} / \mathrm{w})$ total solids content of digester (Tchobanoglous et al., 1993).

\subsection{Digester Configuration and Setup}

Fifteen anaerobic digesters were generally constructed in batch-scale experiments where biogas was produced out of the degradation of organic matter in 1L plastic bottle digester with appropriate working volume. Three plastic bottles were arranged in order in such a way that the first bottle contained substrate, the middle contained acidified brine solution and the last was used for collecting the brine solution that was expelled out from the second bottle. The acidified brine solution was prepared by dissolving $\mathrm{NaCl}$ in distilled water until a supersaturated solution was formed to prevent the dissolution of biogas in the water. Then three drops of sulphuric acid was added using a dropper to acidify the brine solution. The three plastic bottles were interconnected with a plastic tube having a diameter of $1 \mathrm{~cm}$. The tube connecting the first bottle to the second was fitted just above the slurry in the first bottle to help gas collection. Thus, the biogas produced by fermentation of the slurry would be driven from the first bottle to the second bottle that contained a brine solution so as to displace a volume of the brine solution equivalent to the volume of biogas produced. The lids of all digesters were sealed tightly using super glue in order to control the entry of oxygen and loss of biogas. After measuring the initial $\mathrm{pH}$ values of all the digesters, their $\mathrm{pH}$ values were adjusted to be between 6.8 and 7.4 by adding buffer solution. In this experiment $\mathrm{H}_{2} \mathrm{SO}_{4}$ and $\mathrm{NaOH}$, which are strong acid and strong base, respectively were used to adjust the $\mathrm{pH}$ value. In fact there was increase in the $\mathrm{pH}$ values of mixed than solo treatments before adjusting by adding strong acids and bases. The temperature of all the digesters was maintained at $38^{\circ} \mathrm{C}$ (mesophilic condition) by keeping them in an incubator.

\subsection{Liquid content}

As suggested by Tchobanoglous et al. (1993), in each digester, the substrate was mixed with appropriate amount of distilled water and inoculum to achieve the recommended $8 \%(\mathrm{w} / \mathrm{w})$ total solids content in the fermentation slurry. The total amount of liquid (distilled water and rumen fluid) that was added to the digester was determined by the following formula.

$$
\text { Total amont of liquid }=\frac{\text { Mass of total solid }-8 \% \text { mass of fresh substrate }}{8 \%}
$$

Then, by fixing the amount of inoculum $(100 \mathrm{ml})$ that was added finally to facilitate digestion, the amount of distilled water added was determined by using the following formula:

$\mathrm{A}=\mathrm{TL}-100$

Where,

$$
\mathbf{A}=\text { amount of distilled water }
$$

$\mathrm{TL}=$ total amount of liquid

Treatments were randomly arranged in the lab and done in three replicates. The temperatures of bio-digesters were maintained at $38^{\circ} \mathrm{C}$ by keeping them in incubator, which represents mesophilic condition (Knottier, 2003). Initial $\mathrm{pH}$ values were maintained within the $\mathrm{pH}$ range for optimal biogas production (Thy et al., 2003; Yadvika et al., 2004).

\subsection{Biogas Production of Different Combinations of Feedstock}

The amount of gas produced was measured by water displacement method using $90 \% \mathrm{NaCl}$ solution (brine) (Yetilmezsoy and Sakar, 2008). The daily gas production was recorded for different treatments until the gas production ceased. The daily gas produced means the daily acidified brine solution displaced. The volume of biogas produced is egual to the volume of brine solution displaced.

\subsection{Data Analysis}

Data were first checked for their normality. Data that were not normally distributed were log-transformed and thereafter subjected to analysis of variance (one-way ANOVA) using SPSS version 17. Fishers Least Significant Difference (LSD) was used to investigate statistical significance between the different treatments, where as paired samples T-test was used to investigate statistical significance within a treatment. Difference between means was 
considered statistically significant at $P<0.05$.

\section{RESULTS AND DISCUSSION}

\subsection{Physico-chemical Properties of the Substrates Used in Co-digestion}

The Physico-chemical characteristics of BP and PM as main substrates and co-substrates mixed in different ratios for co-digestion were presented in table 2. These parameters were determined before and after AD.

The $\mathrm{pH}$ is important parameter for assessing the efficiencies of anaerobic digester. Some researchers(e.g., Marchaim, 1983) indicated that the optimum biogas production is achieved when the $\mathrm{pH}$ value of the input mixture in the digester is between 6 and 7. There was no significant difference between treatments in pH before AD. The $\mathrm{pH}$ of $100 \% \mathrm{BP}$ slurry and $100 \%$ PM before AD were $6.87 \pm 0.06$ and $6.88 \pm 0.07$, respectively. Though not statistically significant, these values were relatively lower than the two substrates mixed, and this suggests that mixing the two substrates will raise the $\mathrm{pH}$ value toward optimum level recommended for anaerobic digestion in biogas production (Hills and Roberts, 1981). Significant differences were observed between $\mathrm{pH}$ values of before and after $\mathrm{AD}$ in all mix ratios $(P<0.05)$. Changes in $\mathrm{pH}$ may be brought by production of alkali compounds, such as ammonium ions during the degradation of organic compounds in the digester (Gerardi, 2003). The $\mathrm{pH}$ value of the rumen fluid used in all experiments was relatively higher than both substrates $(\mathrm{pH}=7.46)$. This shows that the rumen content used may increased the $\mathrm{pH}$ of treatments. The $\mathrm{pH}$ value increases through ammonia accumulation during degradation of protein while accumulation of volatile fatty acid resulting from degradation of organic matter decreases the $\mathrm{pH}$ value.

No significant $(P<0.05)$ difference was observed between treatments in \% carbon content both in before and after $\mathrm{AD}$. However, $\% \mathrm{C}$ was significantly decreased after $\mathrm{AD}$ in all treatments (Table 2 ). The percent degradation of organic carbon content is one of the indicators for biogas production. Organic carbon can be removed in anaerobic digesters either by being converted to cellular materials for growth and reproduction of bacteria or biogas production (Gerardi, 2003). The decrease in percent carbon reflects the degradation process during anaerobic digestion (Abdel-Hadi and El-Azeem, 2008).

Table 2. Comparison of $\mathrm{pH}, \%$ organic carbon content $\%$ total solid and $\%$ volatile solid between before and after $\mathrm{AD}$ of the various substrates (values are mean $\pm \mathrm{SE}, \mathrm{n}=3$ )

\begin{tabular}{|c|c|c|c|c|c|c|c|c|}
\hline \multirow{3}{*}{$\begin{array}{c}\text { Treatme } \\
\text { nts }\end{array}$} & & & & & \multicolumn{4}{|c|}{ Parameter } \\
\hline & \multicolumn{2}{|c|}{$\% \mathrm{pH}$} & \multicolumn{2}{|c|}{$\% \mathrm{C}$} & \multicolumn{2}{|c|}{$\% \mathrm{TS}$} & \multicolumn{2}{|c|}{$\% \mathrm{VS}$} \\
\hline & Initial & Final & Initial & Final & Initial & Final & Initial & Final \\
\hline $\mathrm{T}-1$ & $\begin{array}{l}6.87 \pm 0.0 \\
6^{\text {Aa }}\end{array}$ & $\begin{array}{l}7.99 \pm 0.2 \\
0^{\mathrm{Ab}}\end{array}$ & $\begin{array}{l}11.98 \pm 0.1 \\
4^{\mathrm{Aa}}\end{array}$ & $\begin{array}{l}9.75 \pm 0.0 \\
5^{\mathrm{Ab}}\end{array}$ & $\begin{array}{l}26.81 \pm 0.0 \\
6^{\mathrm{Aa}}\end{array}$ & $\begin{array}{l}22.94 \pm 0.2 \\
0^{\mathrm{Ab}}\end{array}$ & $\begin{array}{l}21.56 \pm 0.3 \\
0^{\mathrm{Aa}}\end{array}$ & $\begin{array}{l}17.53 \pm 0.1 \\
0^{\mathrm{Ab}}\end{array}$ \\
\hline $\mathrm{T}-2$ & $\begin{array}{l}6.95 \pm 0.0 \\
5^{\mathrm{Aa}}\end{array}$ & $\begin{array}{l}8.23 \pm 0.0 \\
9^{\mathrm{Ab}}\end{array}$ & $\begin{array}{l}11.85 \pm 0.0 \\
6^{\text {Aa }}\end{array}$ & $\begin{array}{l}8.98 \pm 0.0 \\
9^{\mathrm{Ab}}\end{array}$ & $\begin{array}{l}25.94 \pm 0.2 \\
0^{\text {Aa }}\end{array}$ & $\begin{array}{l}20.22 \pm 0.3 \\
2^{\mathrm{Ab}}\end{array}$ & $\begin{array}{l}21.32 \pm 0.1 \\
0^{\text {Aa }}\end{array}$ & $\begin{array}{l}16.18 \pm 0.4 \\
0^{\mathrm{Ab}}\end{array}$ \\
\hline $\mathrm{T}-3$ & $\begin{array}{l}6.94 \pm 0.0 \\
4^{\mathrm{Aa}}\end{array}$ & $\begin{array}{l}8.45 \pm 0.2 \\
4^{\mathrm{Ab}}\end{array}$ & $\begin{array}{l}11.74 \pm 0.0 \\
6^{\text {Aa }}\end{array}$ & $\begin{array}{l}8.15 \pm 0.0 \\
5^{\mathrm{Ab}}\end{array}$ & $\begin{array}{l}25.16 \pm 0.1 \\
5^{\mathrm{Aa}}\end{array}$ & $\begin{array}{l}19.12 \pm 0.3 \\
0^{\mathrm{Ab}}\end{array}$ & $\begin{array}{l}21.11 \pm 0.2 \\
0^{\text {Aa }}\end{array}$ & $\begin{array}{l}14.66 \pm 0.1 \\
0^{\mathrm{Ab}}\end{array}$ \\
\hline $\mathrm{T}-4$ & $\begin{array}{l}6.93 \pm 0.0 \\
6^{\mathrm{Aa}}\end{array}$ & $\begin{array}{l}8.22 \pm 0.2 \\
5^{\mathrm{Ab}}\end{array}$ & $\begin{array}{l}11.61 \pm 0.0 \\
5^{\text {Aa }}\end{array}$ & $\begin{array}{l}8.61 \pm 0.0 \\
3^{\mathrm{Ab}}\end{array}$ & $\begin{array}{l}24.30 \pm 0.4 \\
2^{\text {Аa }}\end{array}$ & $\begin{array}{l}18.17 \pm 0.3 \\
1^{\mathrm{Ab}}\end{array}$ & $\begin{array}{l}20.87 \pm 0.1 \\
0^{\text {Aa }}\end{array}$ & $\begin{array}{l}15.48 \pm 0.0 \\
6^{\mathrm{Ab}}\end{array}$ \\
\hline $\mathrm{T}-5$ & $\begin{array}{l}6.88+0.0 \\
7^{\mathrm{Aa}}\end{array}$ & $\begin{array}{l}8.81 \pm 0.1 \\
3^{\mathrm{Bb}}\end{array}$ & $\begin{array}{l}11.46 \pm 0.0 \\
8^{\mathrm{Aa}}\end{array}$ & $\begin{array}{l}8.78 \pm 0.0 \\
5^{\mathrm{Ab}}\end{array}$ & $\begin{array}{l}23.50 \pm 0.0 \\
6^{\text {Аа }}\end{array}$ & $\begin{array}{l}19.45+0.2 \\
0^{\mathrm{Ab}}\end{array}$ & $\begin{array}{l}20.64 \pm 0.1 \\
5^{\text {Aa }}\end{array}$ & $\begin{array}{l}15.82 \pm 0.2 \\
7^{\mathrm{Ab}}\end{array}$ \\
\hline
\end{tabular}

Means followed by different small letters in row are significant at $P<0.05$ for paired samples T-test within treatment. Means followed by different capital letter in column are significantly different at $P<0.05$ between treatments. $\mathrm{C}=$ carbon, $\mathrm{TS}=$ total solid, $\mathrm{VS}=$ volatile solid, $\mathrm{T}-1=100 \%$ banana fruit peels, $\mathrm{T}-2=75 \%$ banana fruit peels $+25 \%$ poultry manure, $\mathrm{T}-3=50 \%$ banana fruit peels $+50 \%$ poultry manure, $\mathrm{T}-4=25 \%$ banana fruit peels $+75 \%$ poultry manure, $\mathrm{T}-5=100 \%$ poultry manure.

\subsection{Values of TS and VS of Substrate Co-digestion}

Values of TS and VS before and after AD are shown in Table 2. All values are indicated with mean $\pm \mathrm{SE}$ (standard error values) for each treatment.

No significant $(P<0.05)$ difference was observed between treatments in $\% \mathrm{TS}$ and $\% \mathrm{VS}$ both in before and after AD. However, their values were significantly decreased after AD in all treatments (Table 2). Total solids (TS) of all treatments before anaerobic digestion was between $2.681 \mathrm{~g}(26.81 \pm 0.06)$ and $2.35 \mathrm{~g}(23.50 \pm 0.06)$ from $10 \mathrm{~g}$ sample of each treatment. The maximum initial TS was recorded in $100 \% \mathrm{BP}$ and the minimum initial TS was recorded in $100 \% \mathrm{PM}$. The maximum TS of BP may be due to its high fiber content. The TS of all treatments decreased after anaerobic digestion in this experiment. However, the extent of decrement relatively appears to be greater in mixed substrates than sole substrates. This might be because of more balanced acidogenesis and methanogenesis in mixed substrates than sole substrates. The TS content of $23.50 \%$ of $100 \%$ PM used for this experiment is in the range of 10 to $30 \%$ TS reported by Braun et al. (1981) for poultry manure. Among the mixed 
treatments the highest TS decrement was recorded in $25 \% \mathrm{BP}+75 \% \mathrm{PM}$ and from total treatments in the experiment, the smallest decrement after $\mathrm{AD}$ was recorded in $100 \% \mathrm{BP}$.

The decrement of VS is another parameter that indicates the production of biogas from organic substances. In this experiment the maximum initial VS was recorded in $100 \%$ BP $(21.56 \pm 0.30)$ and the minimum initial VS was recorded in $100 \%$ PM $(20.64 \pm 0.15)$. In the same manner to TS, VS of all treatments decreased after anaerobic digestion in the experiment, but the decrement was more pronounced again in mixed treatments. The maximum decrement of VS was observed in $50 \% \mathrm{BP}+50 \% \mathrm{PM}(21.11 \pm 0.20$ to $14.66 \pm 0.10)$ as indicated in Table 2 . Before anaerobic digestion, TS of 100\%PM was 23.50 and VS as \% of TS was $87.83 \%$ and after anaerobic digestion, TS was 19.45 and VS as \% of TS was $81.34 \%$ after AD. This is in accordance with Fulford (1988), who reported that the composition of animal and human wastes typically consist of 15-48 percent of TS and the VS is 77-90 percent of the TS. Compared to the values measured before anaerobic digestion, TS and VS significantly $(P<0.05)$ decreased after anaerobic digestion for all treatments. Thus total solids and volatile solids destruction is a good parameter for evaluating the efficiency of anaerobic digestion (Abubaker and Ismail, 2012), and it is a good indicator of biogas production (Rafique et al., 2010).

The mixing of several wastes for anaerobic digestion can utilize the nutrients and bacterial diversities that could provide buffering capacity and improved $\mathrm{C} / \mathrm{N}$ ratio, thereby decreasing the risk of ammonia inhibition to the digestion process (Macias-Corral et al., 2008). This by itself shows mixing waste organic materials increases biogas production as indicated in table 2; maximum TS and VS reduction was recorded in mixed treatments than in solo treatment with either BP or PM.

\subsection{Average Daily and Cumulative Biogas Production of Substrates}

Gas production was noticed from the very initial day of measurement, though the volume produced varied with substrate mixture in the experiment (Fig. 2). This could be due to the presence of microbes in the rumen fluid inoculums and readily available organic nutrients that are easily digestible by microbes (Kamthunzi, 2008). At the beginning, the digesters with $\mathrm{PM}$ alone and $25 \% \mathrm{BP}+75 \% \mathrm{PM}$ (highest proportion of poultry manure) produced maximum (in $\mathrm{ml}$ ) amount of biogas compared to the others. This could be due to the presence of higher amount of readily biodegradable organic matter and native anaerobic microbes in the PM than in others (Hobson, 1981; Yeole and Ranande, 1992). Thus, biogas production is a function of the feedstock's organic content and its biodegradability (Macias-Corral et al., 2008). Biogas production was minimum (in ml) in 100\% BP at initial days compared to others because the substrate is with high fiber content that requires longer hydraulic retention time to be digested (Mattocks; 2002). Biogas production showed fluctuating decline after the first day of measurement and eventually reached $0 \mathrm{ml}$ on the 26th day of the experiment for all substrates. This may be attributed to the depletion of the necessary nutrients from the digesters and the increase in ammonium concentration that resulted in an increased $\mathrm{pH}$ values to inhibit digestion (Hansen et al., 1998).

The cumulative biogas produced shows a significant $(P<0.05)$ difference between the substrates in an overall biogas yield (Fig 3). Higher cumulative biogas was recorded in mixed substrate types than sole substrates, with the highest cumulative biogas production observed in $50 \% \mathrm{BP}+50 \% \mathrm{PM}$. The minimum cumulative biogas production was recorded in $100 \% \mathrm{BP}$ this could be because of high fiber content, which is less digestible by microorganisms resulting in less VS decrement. Even though TS of 100\% BP was higher than mixtures, it did not produce more biogas than mixed substrates. This might be due to its fibre content and the less favourable situation of $100 \% \mathrm{BP}$ to microorganisms as compared to the substrate mixtures. Less cumulative biogas of banana fruit peels could be because of its acidic nature, as Maishanu and Seekimpi (1988) and Anonymous (1992) observed that microbes require neutral or mild alkaline conditions for optimal biogas production. 


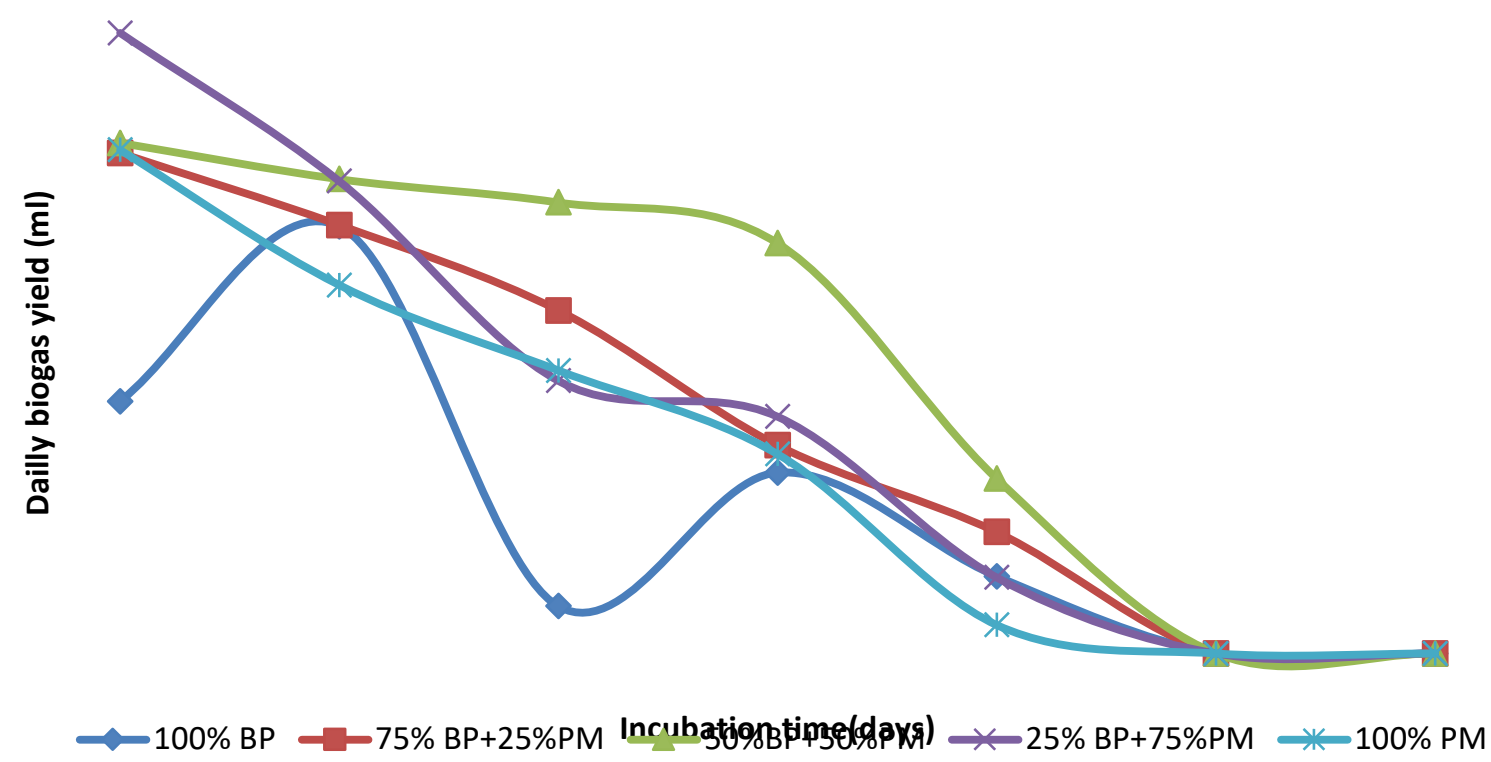

Figure 2. Daily mean Biogas yield of the different substrate proportion in each treatment.

From $50 \% \mathrm{BP}+50 \% \mathrm{PM}, 994 \mathrm{ml}$ (Appendix table 7.1) of biogas was produced, this was $409 \mathrm{ml}$ higher than $100 \% \mathrm{BP}$, which produced $585 \mathrm{ml}$ of cumulative biogas. This could be concluded that the higher production of biogas from the mixtures could be due to a proper nutrient balance, increased buffering capacity, and decreased effect of toxic compounds resulting from mixing of the substrates (Fulford, 1988; Macias-Corral et al., 2008; Li et al., 2009; Tamirat, 2012). The benefits of co-digesting plant materials with animal manure were first reported by Hills and Roberts (1981), by which it was found that manure could provide buffering capacity and a wide range of nutrients, while the added plant materials with high carbon content could improve the $\mathrm{C} / \mathrm{N}$ ratio of the feedstock, thereby decreasing the risk of ammonia inhibition to the digestion process. So, this indicates that mixing substrates maximizes biogas production which supports this research.

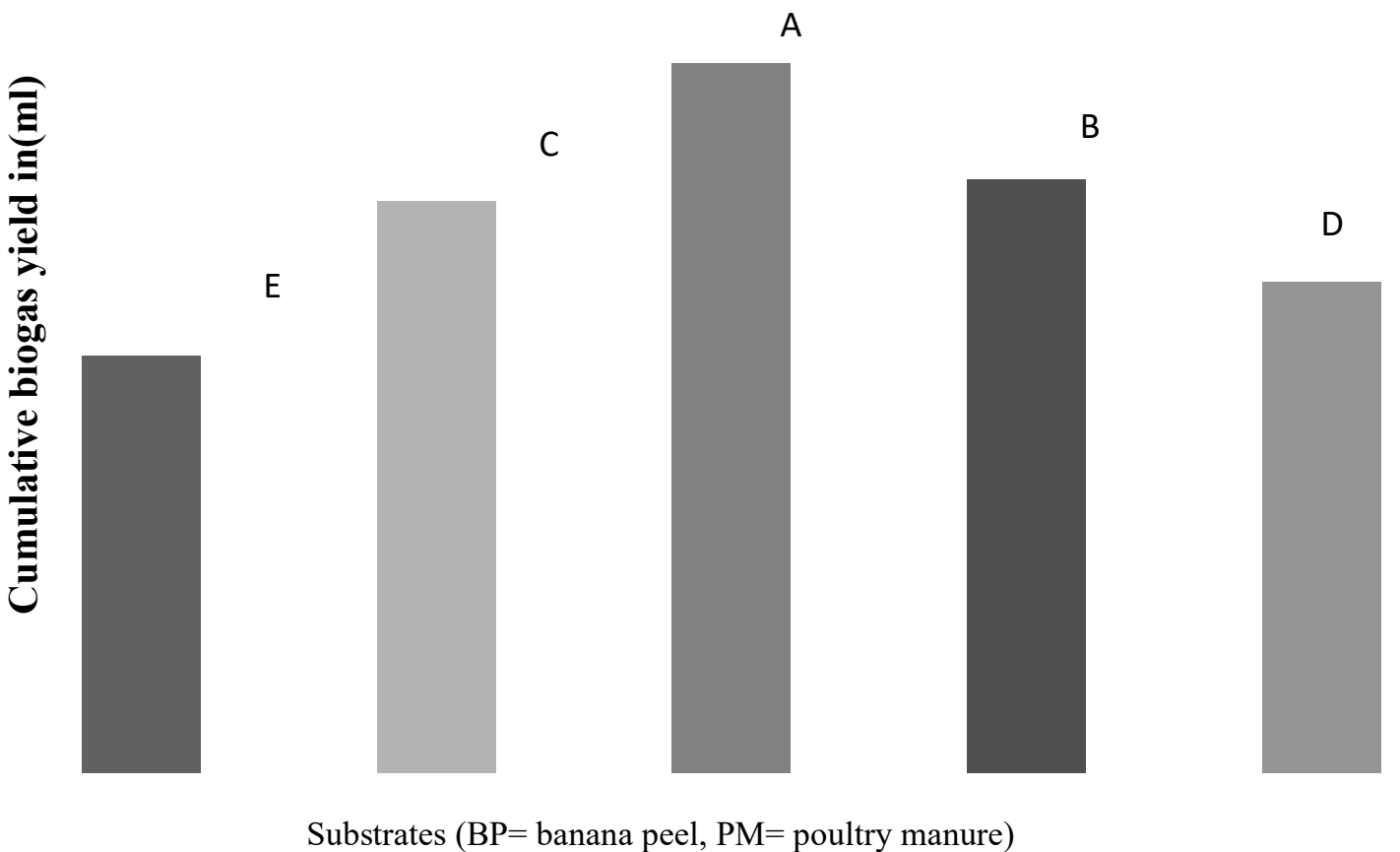

Figure 3. Cumulative biogas yield of the different substrate combinations (Values are mean $\pm \mathrm{SE}$ ). Bars with different Capital letters indicate significant differences between mean. 
In general, both banana fruit peels and poultry manure have potential for production of biogas and its remaining slurry could be used as fertilizer. As indicated in this work and by many researchers mixing substrates are important to obtain maximum yield of biogas. The optimum mix ratio according to this research was found to be $50 \% \mathrm{BP}+50 \% \mathrm{PM}$ for substrates.

Daily mean biogas yields $(\mathrm{ml})$ from co-digestion of banana peel, poultry manure and their mixtures at different ratios $\pm \mathrm{SE}(\mathrm{ml})(\mathrm{n}=3)$

\begin{tabular}{|c|c|c|c|c|c|}
\hline & \multicolumn{5}{|c|}{ Mix ratios } \\
\hline Days & $100 \% \mathrm{BP}$ & $75 \% \mathrm{BP}+25 \% \mathrm{PM}$ & $50 \% \mathrm{BP}+50 \% \mathrm{PM}$ & $25 \% \mathrm{BP}+75 \% \mathrm{PM}$ & $100 \% \mathrm{PM}$ \\
\hline D1 & $18 \pm 1.00$ & $36 \pm 3.20$ & $43 \pm 3.00$ & $48.33 \pm 5.84$ & $54.67 \pm 5.34$ \\
\hline D2 & $25.67 \pm 2.08$ & $68 \pm 2.00$ & $59 \pm 8.55$ & $78 \pm 4.00$ & $60.22 \pm 8.12$ \\
\hline D3 & $16 \pm 2.54$ & $57.33 \pm 1.55$ & $41 \pm 4.20$ & $61.67 \pm 2.34$ & $32 \pm 2.50$ \\
\hline D4 & $19.33 \pm 1.53$ & $48.33 \pm 2.2$ & $58.33 \pm 11.24$ & $62 \pm 8.00$ & $51 \pm 11.50$ \\
\hline D5 & $47 \pm 10.50$ & $40.33 \pm 5.58$ & $53.67 \pm 10.87$ & $60 \pm 15.50$ & $53.67 \pm 16.68$ \\
\hline D6 & $48 \pm 2.20$ & $63.67 \pm 8.42$ & $44.67 \pm 12.22$ & $38.67 \pm 19.53$ & $52 \pm 22.47$ \\
\hline D7 & $45.67 \pm 2.52$ & $36.67 \pm 7.54$ & $54.67 \pm 9.32$ & $61.67 \pm 15.17$ & $38.67 \pm 6.52$ \\
\hline D8 & $36.33 \pm 2.80$ & $27.33 \pm 4.64$ & $43.67 \pm 5.56$ & $39.33 \pm 1.84$ & $34 \pm 2.54$ \\
\hline D9 & $37 \pm 4.00$ & $22 \pm 1.00$ & $35.67 \pm 6.45$ & $64.33 \pm 10.23$ & $22.33 \pm 1.34$ \\
\hline D10 & $46.4 \pm 3.40$ & $64.33 \pm 3.2$ & $58.33 \pm 10.33$ & $32 \pm 4.20$ & $37 \pm 7.50$ \\
\hline D11 & $20 \pm 5.78$ & $51 \pm 11.42$ & $58 \pm 13.00$ & $27.33 \pm 3.84$ & $20 \pm 13.24$ \\
\hline D12 & $26.33 \pm 4.50$ & $33 \pm 6.24$ & $51.33 \pm 8.46$ & $26 \pm 2.00$ & $41.33 \pm 6.34$ \\
\hline D13 & $23.33 \pm 9.50$ & $27 \pm 6.00$ & $48.33 \pm 2.52$ & $33.33 \pm 3.67$ & $27.67 \pm 4.17$ \\
\hline D14 & $23.67 \pm 5.50$ & $26.67 \pm 8.67$ & $42.33 \pm 8.50$ & $24.33 \pm 1.34$ & $28.33 \pm 5.34$ \\
\hline D15 & $23.8 \pm 2.00$ & $33.67 \pm 3.12$ & $25.33 \pm 3.48$ & $25.33 \pm 0.84$ & $24 \pm 3.64$ \\
\hline D16 & $21 \pm 1.00$ & $20.33 \pm 3.64$ & $50.33 \pm 10.50$ & $22.67 \pm 5.52$ & $19.67 \pm 1.33$ \\
\hline D17 & $25.33 \pm 10.50$ & $38 \pm 9.50$ & $51 \pm 9$ & $29 \pm 5.50$ & $30 \pm 2.50$ \\
\hline D18 & $18.33 \pm 1.53$ & $20.33 \pm 1.95$ & $48.33 \pm 1.58$ & $21 \pm 4.00$ & $25 \pm 6.28$ \\
\hline D19 & $13.67 \pm 3.05$ & $11 \pm 2$ & $30.67 \pm 3.50$ & $20.67 \pm 6.46$ & $12.67 \pm 1.67$ \\
\hline D20 & $12.33 \pm 0.58$ & $14.33 \pm 3.52$ & $24.67 \pm 5.52$ & $25 \pm 7.50$ & $12.33 \pm 0.67$ \\
\hline D21 & $10 \pm 4.60$ & $12 \pm 2$ & $15 \pm 5$ & $10.33 \pm 2.34$ & $10 \pm 2.20$ \\
\hline D22 & $7.33 \pm 0.58$ & $16 \pm 2.4$ & $32 \pm 1.50$ & $9 \pm 2.50$ & $4.33 \pm 1.34$ \\
\hline D23 & $11 \pm 20$ & $17.33 \pm 3.22$ & $21.67 \pm 1.72$ & $14.67 \pm 0.66$ & $0 \pm 00$ \\
\hline D24 & $6 \pm 10$ & $12.67 \pm 4.4$ & $16 \pm 20$ & $4 \pm 2.00$ & $0 \pm 00$ \\
\hline D25 & $4.2 \pm 0.4$ & $2.67 \pm 1.64$ & $2.67 \pm 1.34$ & $0 \pm 00$ & $0 \pm 00$ \\
\hline D26 & $0 \pm 00$ & $0 \pm 00$ & $0 \pm 00$ & $0 \pm 00$ & $0 \pm 00$ \\
\hline D27 & $0 \pm 00$ & $0 \pm 00$ & $0 \pm 00$ & $0 \pm 00$ & $0 \pm 00$ \\
\hline Total & 585 & 801 & 994 & 832 & 688 \\
\hline
\end{tabular}

\section{SUMMARY, CONCLUSIONS AND RECOMMENDATIONS}

\subsection{Summary}

World energy consumption has increased steadily over the last century as the world population has grown and more countries have become industrialized. Biogas technology is a modern and eco-friendly technology based on the decomposition of organic materials in anaerobic environment at suitable and stable temperature by anaerobic bacteria. Fruit peels are biodegradable in nature and are a potential source for the production of biogas. So the objective of this study was to evaluate biogas production from banana fruit peel and co-digestion with poultry manure. In some parts of Ethiopia, there is a huge potential of banana fruit peel that affects environment \& health of human, but may be used as raw material for biogas production (waste to energy). Anaerobic digestion tests were carried out to obtain suitable mix ratio for maximum biogas production from co-digestion of BP and PM at five different treatments with different ratios. The experiment was carried in $1 \mathrm{~L}$ digester in incubator under mesophilic condition $\left(38^{0} \mathrm{c}\right)$ for 27 days of hydraulic retention time.

\subsection{Conclusion}

Animal wastes like poultry manure and fruit peels like banana peel are important sources for biogas production. In this experiment poultry manure and banana fruit peel alone and in different mix ratios were used as raw materials. Biogas production from $100 \% \mathrm{BP}, 75 \% \mathrm{BP}+25 \% \mathrm{PM}, 50 \% \mathrm{BP}+50 \% \mathrm{PM}, 25 \% \mathrm{BP}+75 \% \mathrm{PM}$ and $100 \% \mathrm{PM}$ was recorded. The maximum biogas was produced from mixture substrates opposed to sole substrates. From five different tests maximum biogas production was recorded in $50 \% \mathrm{BP}+50 \% \mathrm{PM}$ based on high reduction of $\% \mathrm{VS}, \% \mathrm{TS}$ and $\% \mathrm{C}$.

Cumulative biogas production from 100\%BP was minimum compared to other treatments; this could be because of fiber content in banana fruit peel. This indicates that mixing substrates improves biogas production. In 
general, the significance of using these plant materials and animal manures as a substrate for biogas production is doubly laden, i.e., it is a win-win approach (waste to energy) of utilizing a raw material and remaining slurry could be used as organic fertilizer.

\subsection{Recommendations}

* Countries like Ethiopia with developing industries should look for different energy sources. Biogas is among these energy sources, which could be obtained from environmental wastes including animal manures and fruit peels. It is recommended for all households to use biogas technology to get energy for home use and to make their environment clean.

* It is crucial to carry out further investigation like amount of fiber content, microbial community profile, accumulation and reduction of volatile fatty acid, quantity of ammonia nitrogen, and methane quality using Gas Chromatograph for better optimization of the process.

* This investigation was done at mesophilic temperature $\left(38^{\circ} \mathrm{C}\right)$ only but it should be carried out at different temperatures like room temperature $\left(24^{\circ} \mathrm{C}\right)$ and thermophilic conditions $\left(55^{\circ} \mathrm{C}\right)$; and also using pre- treatments with different chemicals and physical agents.

\section{REFERENCES}

Abdel-Hadi, M.A. and S.A.M. Abd El-Azeem, 2008. Effect of heating, mixing and digestertype on biogas production from buffalo dung. Misr J. Agric. Eng. 25(4): 1454-1477.

Abuabaker, B. and N. Ismail. 2012. Anaerobic Digestion of Cow Dung for Biogas Production. ARPN J. Eng. Appl. Sci. 7 (2):169-172.

Anonymous,1981. Biogas technology and utilization.A statusReport. Departmentof Scienceand Technology, Government of India, New Delhi.20-46.098UUJK, L.

APHA, 1999. Standard Methods for the Examination of Water and Waste water, $19^{\text {th }}$ ed American Public Health association, Washington DC.

Braun, R., P. Huber and J. Meyrath. 1981. Ammonia toxicity in liquid piggery manure digestion. Biotech. Lett. $3: 159-164$

Claude, J. 2009. Making a Link Between Biogas and Organic Agriculture in Africa. Kampala, Rwanda. http://www.unep-unctad.org/cbtf/organicagriculture.asp Accessed on, August 6, 2014.

Converti . 2009. Biogas production and valorization by means of a two-step biological process, Bioresource Technology, Issue. 100,2009, pp. 5771 - 5776.

FAO. 2009. Coping with a changing climate: Consideration for adaptation and mitigation in agriculture. Environment and Natural Resources Management series 15, Rome

Fisseha Tegegn. 1991. Biogas in Ethiopia, Ethiopian energy authority. http://www.sciencepublishinggroup.com/journal/paperin Accessed on, May 19, 2014

Fulford, D. 1988. Running a biogas programme, a handbook. Intermediate technology Publications, London. $123 \mathrm{pp}$.

Gerardi, M.H. 2003. The Microbiology of Anaerobic Digesters. A John Wiley \& Sons, Inc. pp. 99-103

Hansen, K., I. Angelidaki and B.K. Ahring, 1998. Anaerobic digestion of swine manure: inhibition by ammonia. Water Res. 32 (1):5-2.

Hills, D. J. and D.W. Roberts. 1981. Anaerobic digestion of dairy manure and field crop residues. Agric. Wastes 3:179-189.

Haug and Jigar. 1993. Academic Journals http://www.academicjournals.org/article Accessed on, July 19, 2014

Hobson, P.N., S. Bousfield and R. Summers, 1981. Methane production from agricultural and domestic waste. Applied science publisher

Kamthunzi, W.M. 2008. Anaerobic digestion of cattle manure in batch digesters at ambient temperature. Environ Sci. Technol. 3: 8-12.

Knottier, M. 2003. Integration of biogas technology, organic farming and energy crops. The futures of biogas in Europe II, European biogas Work shop .university of southern Denmark, Denmark.

Macias-Corral, M. Z., Samani, A., Hanson, G., Smith, P., Funk, H. Yu and J. Longworth. 2008. Anaerobic digestion of municipal solid waste and agricultural waste and the effect of co-digestion with dairy cow dung. Bioresour. Technol. 99:8288-8293.

Marchaim, U. 1983. 3rd International Symposium on Anaerobic Digestion, Boston, MA, pp. 343-355.

Mattocks, R. 2002. Understanding Biogas. Countryside and small Stock Journal; 86(4). July/Aug Sci. Module

Popescu. 2010. Constantin, Mastorakis Nikos, Aspects regarding the use of renewable energy in EU Countries, WSEAS Transactions on Environment and Development, Issue 4, Volume 6, 2010, pp. 265 - 275.

Rafique, R., T.P. Gorm, A. Nizami, Z. Asam, D.M. Jerry and G. Kiely. 2010. Effect of thermal, chemical and thermo-chemical pre-treatments to enhance methane production. Energy. 35:4556-4561.

Siltan Abrha. 1985. A brief note on biogas technology, Ministry of mine and energy, Ethiopian national energy 
committee. Pp 29-31.

Tchobanoglous, G., H. Theisen and S. Vigil, 1993. Integrated Solid Waste Management Engineering: Principle and Management Issues. Singapore, McGraw-Hill U.S.

Thy, S., T.R. Preston and J. Ly, 2003. Effect of retention time on gas production and fertilizer valueof biodigesters effluent. Livest Res Rural Dev. 15(7):1-24

Werner Uli, Ulrich Stöhr. and Nicolai Hees. 1989. Biogas plants in animal husbandry, A Publication of the Deutsches Zentrumfür Entwicklungs technology. GATE a Division of the Deutsche Gesellschaftfür Technische Zusammenarbeit (GTZ).

Yadvika Santosh, Sreekrshnan, T.R., Kohil S. and Rana. 2004. Enhancement of biogas production from solid substrates using different techniques: Bioresource Technology 95:1-10.

Yeole, T.Y. and D.R. Ranande, 1992. Alternative feedstock for Biogas. Trop anim prod. 9(3):10-16.

Yetilmezsoy and Sakar. 2008. The Influence of Total Solid Contents on Biogas Yield from Cattle Manure Using Rumen Fluid Inoculum. Energy Research Journal 1 (1): 6-11

Zenebe Gebreegziabher, Alemu Mekonnen, Menale Kassie and Gunnar Köhlin. 2010. Urban Energy Transition and Technology Adoption, the Case of Tigrai, Northern Ethiopia, Environment for development. Discussion paper series August 2010 EfD DP 10-22 